\title{
Effects of Protein Supplementation Combined with Exercise Training on Muscle Mass and Function in Older Adults with Lower-Extremity Osteoarthritis: A Systematic Review and Meta-Analysis of Randomized Trials
}

\author{
Chun-De Liao ${ }^{1,2}{ }^{\oplus}$, Yen-Tzu Wu ${ }^{1,3}{ }^{\mathbb{D}}$, Jau-Yih Tsauo ${ }^{1}$, Pey-Rong Chen ${ }^{4,5}$, Yu-Kang Tu ${ }^{6} \oplus$, \\ Hung-Chou Chen ${ }^{2,7}$ and Tsan-Hon Liou $2,7, *$ (D) \\ 1 School and Graduate Institute of Physical Therapy, College of Medicine, National Taiwan University, \\ Taipei 100025, Taiwan; 08415@s.tmu.edu.tw (C.-D.L.); yenwu@ntu.edu.tw (Y.-T.W.); \\ jytsauo@ntu.edu.tw (J.-Y.T.) \\ 2 Department of Physical Medicine and Rehabilitation, Shuang Ho Hospital, Taipei Medical University, \\ New Taipei City 235041, Taiwan; 10462@s.tmu.edu.tw \\ 3 Physical Therapy Center, National Taiwan University Hospital, Taipei 100229, Taiwan \\ 4 Department of Dietetics, National Taiwan University Hospital, Taipei 100225, Taiwan; prchen@ntuh.gov.tw \\ 5 School of Nutrition and Health Sciences, Taipei Medical University, Taipei 110301, Taiwan \\ 6 Institute of Epidemiology and Preventive Medicine, College of Public Health, National Taiwan University, \\ Taipei 100025, Taiwan; yukangtu@ntu.edu.tw \\ 7 Department of Physical Medicine and Rehabilitation, School of Medicine, College of Medicine, \\ Taipei Medical University, Taipei 110301, Taiwan \\ * Correspondence: peter_liou@s.tmu.edu.tw; Tel.: +886-2-2249-0088 (ext. 1600); Fax: +886-2-2248-0577
}

Received: 14 July 2020; Accepted: 10 August 2020; Published: 12 August 2020

\begin{abstract}
Aging and osteoarthritis (OA) are associated with a high risk of muscle mass loss, which can lead to physical disability. This study investigated the effectiveness of protein supplementation combined with exercise training (PS + ET) in improving muscle mass and functional outcomes in older adults with lower-limb OA. A comprehensive search of online databases was performed to identify randomized controlled trials (RCTs) on the effectiveness of PS + ET in older adults with hip or knee OA. Meta-analysis and risk of bias assessment of the included RCTs were conducted. Six RCTs were included in this systemic review; they had a median (range/total) Physiotherapy Evidence Database (PEDro) score of 7 (6-9) out of 10, respectively. Five RCTs that enrolled patients who underwent total joint replacement were included in this meta-analysis. The PS + ET group exhibited significant improvements in muscle mass (standard mean difference [SMD] $=1.13, p<0.00001$ ), pain $(\mathrm{SMD}=1.36, p<0.00001)$, and muscle strength $(\mathrm{SMD}=0.44, p=0.04)$. Our findings suggest that PS + ET improves muscle mass, muscle strength, and functional outcomes and reduces pain in older adults with lower-limb OA, particularly in those who have undergone total joint replacement.
\end{abstract}

Keywords: osteoarthritis; sarcopenia; arthroplasty; protein supplement; exercise training; muscle mass; physical function

\section{Introduction}

Osteoarthritis (OA), especially in joints in the lower extremity, is one of the most prevalent musculoskeletal diseases in older adults [1]. Its prevalence increases rapidly from the sixth to ninth 
decades of life, and it is a major health issue at individuals and population levels [2]. In particular, hip or knee OA is associated with impaired functional activity, potentially leading to disability [3].

Deficits in muscle volume and function have been observed in older adults with mild to moderate hip OA [4] as well as in people with mild to severe knee OA [5]. Such deterioration of muscle mass occurring with disease progression has been attributed to sarcopenia, a condition associated with muscle attenuation in older adults [6]. Recently, it has been reported that older adults with knee OA are at a high risk of sarcopenia [7]. This finding of high risk is based on previous observations that older adults with OA have lower appendicular lean mass in the lower limbs relative to healthy controls [8], and that low skeletal muscle mass is independently associated with radiographic knee OA [9]. Because lower-limb lean mass is closely associated with muscle power in OA [10] and because low skeletal muscle mass is closely associated with physical difficulty and poor health status among older adults [11,12], sarcopenia may lead to physical decline through muscle weakness during OA progression. Therefore, the maintenance of muscle strength and the prevention of sarcopenia are crucial for enabling older adults with hip or knee OA to successfully perform physical tasks.

$\mathrm{OA}$ has been recognized as a major musculoskeletal disease [13]. The management of mild to moderate OA comprises multidisciplinary interventions, including pain medications and nonpharmacological treatments; however, for end-stage OA, total joint replacement is recommended [14]. Several recent studies have indicated physical activity and nutrition as nonpharmacological and preventive treatments for OA and sarcopenia [15-19]. Among treatment interventions for OA, exercise training (ET) has been recommended as the first-line treatment [20]. In addition, conservative ET-administered in combination with a variety of training tools, such as kinesio tape [21] and whole-body vibration (or electromyostimulation) [19] — has been effectively employed to improve muscle mass, muscle strength, and physical function [19,22]. Additionally, dietary interventions, such as dietary protein or protein supplementation (PS), have been incorporated into the multidisciplinary management of OA [23-25]. Studies have noted that $30.3 \%-65.1 \%$ of older adults with knee or hip OA had a daily protein intake lower than the recommended daily allowance of $0.8 \mathrm{~g} / \mathrm{kg} /$ day [26,27]. PS and protein-based diet interventions are believed to additionally increase the efficacy of ET in older adults [28,29]. However, inconsistent results have been obtained regarding the effectiveness of PS combined with ET (PS + ET), specifically in older adults with OA or in individuals who recently underwent total joint replacement. Previous studies have shown that PS + ET significantly improved muscle mass [30] and strength [31,32] in older adults with OA, but other studies have not [33,34]. Because older adults with OA have a high risk of sarcopenia [7], which may further affect postoperative outcomes in those who have recently undergone total joint replacement [33-35], the skeletal muscle plays an important role in functional recovery after total joint replacement and has thus been targeted in the management of OA $[7,36,37]$. Therefore, determining the effectiveness of PS + ET in preserving muscle mass in older adults with OA is crucial, especially in those who have recently undergone total joint replacement.

Evidence regarding the effects of PS + ET on healthy, sarcopenic, and frail older adults has been well established by previous systematic reviews and meta-analyses [38-40]; however, few studies have focused on older adults with OA or those who underwent total joint replacement. Thus, this study examined the effects of PS + ET on muscle mass and functional outcomes in older adults with OA in the lower extremity.

\section{Method}

\subsection{Design}

The present study was conducted in accordance with guidelines of the Preferred Reporting Items for Systematic Reviews and Meta-Analysis (PRISMA) [41]. The study protocol has been registered at PROSPERO (registration number: CRD42020176748). In this study, comprehensive searches of online databases were conducted, namely PubMed, EMBASE, the Cochrane Library 
Database, the Physiotherapy Evidence Database (PEDro), China Knowledge Resource Integrated Database, and Google Scholar. The secondary sources referred to in this study comprised papers cited by the articles obtained from the database searches. No limitations were imposed on publication year and language to minimize publication and language biases. Two authors (CDL and HCC) independently searched for relevant articles, screened them, and extracted data. Any disagreement between the authors was resolved through a consensus reached with the other team members (YTW and THL), who acted as arbitrators.

\subsection{Search Strategy}

The following keywords were used to identify participant characteristics: ("older adults" or "elder adults") and ("osteoarthritis" or "arthroplasty"). The following keywords were used to identify the study intervention: ("exercise training" or "physical activity") and ("protein/amino-acid/nutrient supplementation" or "nutrition intervention"). The search formulas for each database are detailed in Supplementary Table S1.

\subsection{Selection Criteria of Studies}

Trials were included if they met all of the following criteria: (1) the study was a randomized controlled trial (RCT); (2) the study enrolled participants who were aged $\geq 50$ years, had a radiographic diagnosis of hip or knee OA with a Kellgren-Lawrence (K-L) grade of $\geq$ II for disease severity [42], and had undergone total joint replacement (or not); (3) the experimental groups received PS + ET; (4) the exercise intervention included either resistance-based ET (RET) alone or a multicomponent exercise regime (MET) that comprised RET, aerobic exercise, balance training, and physical activity training; (5) the control group received a comparative intervention, including a placebo supplement, PS alone, ET alone, or none of the above (i.e., regular care); (6) the supplementation intervention involved protein sources, including whey protein, milk protein, leucine, and casein, whether consumed alone or in combination with other nutrients (creatine and amino acids); (7) the PS + ET intervention was applied either preoperatively or postoperatively to participants who underwent arthroplasty or replacement surgery for the knee or hip joint; and (8) the study reported measures on at least one of the primary outcomes of muscle mass, pain, and muscle strength. The definitions of these outcomes are provided in the following subsections.

Studies were excluded if (1) the trial was conducted in vitro or in vivo in an animal model or (2) the trial had a non-RCT design (e.g., case report, case series, or prospectively designed trial without a comparison group).

\subsection{Outcome Measures}

In this study, the primary outcomes of interest were measures of pain, muscle mass, and muscle strength. The muscle mass measures included but were not limited to lean body mass, fat-free mass, appendicular lean mass, muscle cross-sectional area (CSA), muscle volume, and muscle thickness. Pain was measured using a perceived-report scale, such as the visual analog scale.

The secondary outcomes of interest comprised physical mobility (specifically, walking capability, chair-rise performance, and timed up-and-go performance); physical activity; patient-reported global functioning; and levels of inflammatory biomarkers of OA, such as C-reactive protein (CRP), interleukin-6 (IL-6), and tumor necrosis factor- $\alpha$ (TNF- $\alpha$ ) [43]. Specifically, walking capability was assessed using walking task outcomes, such as $10-\mathrm{m}$ walk time and timed 6-min walk distance test outcomes. Patient-reported global functioning was assessed using a perceived function scale, such as the Harris Hip Score (HHS) [44], the Knee injury and Osteoarthritis Outcome Score (KOOS) [45], and the 36-Item Short-Form Health Survey (SF-36) physical score [46]. If improved patient condition is indicated by a negative score change for a measure (e.g., pain score and timed up-and-go performance), score changes for that measure had their signs inverted in the meta-analyses. 


\subsection{Data Extraction}

Data on the following were extracted from each included trial and are presented in an evidence table: (1) characteristics of the study sample and research design, including group design and participant type; (2) characteristics of ET and PS interventions; (3) measured time points; and (4) main outcome measures. One author (CDL) extracted the relevant data from the included trials, and another author (HCC) reviewed the extracted data. Any disagreement between the two authors was resolved through discussion to reach a consensus. A third author (THL) was consulted if a consensus could not be reached.

\subsection{Assessment of Risk of Bias and Methodological Quality of Included Studies}

To assess the quality of the included trials, the PEDro quality score was estimated for assessing the risk of bias. Two researchers independently assessed the methodological quality of each of the included studies in accordance with the PEDro classification scale, which is a valid measurement tool of the methodological quality of clinical trials [47]. The PEDro scale comprises 10 items: random allocation, concealed allocation, similarity at baseline, subject blinding, therapist blinding, assessor blinding, $>85 \%$ follow-up for at least one key outcome, intention-to-treat analysis, between-group statistical comparison for at least one key outcome, and point and variability measures for at least one key outcome. Each item is scored as either 1 (present) or 0 (absent), with the total score ranging from 0 to 10 . The validity and reliability of the PEDro scale have been verified in previous studies: an inter-rater reliability generalized kappa statistic between 0.53 and 0.94 was reported [48], and an intraclass correlation coefficient of 0.91 [95\% confidence interval (CI): 0.84-0.95] was found for the cumulative PEDro score in a nonpharmacological study [49]. In this study, the methodological quality of the included RCTs was rated as high $(\geq 7)$, medium (4-6), or low $(\leq 3)$ based on the total PEDro score (which is 10) [50].

\subsection{Data Synthesis and Analysis}

We computed effect sizes for each study separately for primary and secondary outcome measures. The primary and secondary outcome measures were defined as a pooled estimate of the mean difference in the change between the treatment (i.e., PS + ET) and control (i.e., ET with or without placebo supplementation) groups. If the exact variance of the paired difference was not derivable, the variance was imputed by assuming the within-participant correlation coefficients-between the baseline and post-test measured data-of 0.98 for muscle mass [51], 0.92 for muscle strength [52,53], 0.8 for mobility [53,54], and 0.5 for patient-reported pain and global functioning [55]. All extracted outcome data were transformed into the mean difference (MD) relative to the control. When different scales, we used the standardized MD (SMD) for meta-analysis were used to measure the same outcome (e.g., pain and muscle strength) [56]. Follow-up duration was assessed and classified into short-term ( $\leq 1$ month), medium-term ( $>1$ month and $<6$ months), and long-term ( $\geq 6$ months) durations.

Fixed-effect or random-effect models were used depending on the presence of heterogeneity. Statistical heterogeneity was assessed using the $I^{2}$ statistic, with significance at $p<0.05$ [57]. A fixed-effect model was used unless statistical heterogeneity was significant, in which case a random-effect model was used.

The follow-up duration was assessed and defined as short term ( $\leq 1$ month), medium term ( $>1$ month and $<6$ months), and long term ( $\geq 6$ months).

If heterogeneity was significant, subgroup analyses were further performed to explore the potential modifiers of PS + ET treatment effects [57]. The subgroup analyses considered the following: (1) participant-related factors, including sex, body mass index $\left(\geq 30 \mathrm{~kg} / \mathrm{m}^{2}\right.$ or $\left.<30 \mathrm{~kg} / \mathrm{m}^{2}\right)$, and involved joint (hip or knee); (2) study design-related factors, including methodological quality (PEDro score $\geq 7$ or $<7$ ); and (3) intervention-related factors, including PS dose ( $\geq 40 \mathrm{~g} /$ day or $<40 \mathrm{~g} /$ day [58]) and duration of intervention. All subgroup differences were tested for significance, and the $I^{2}$ statistic was also 
computed to estimate the degree of subgroup variability. Potential publication bias was investigated through the initial visual inspection of a funnel plot for reporting bias [59] and a subsequent Egger's regression asymmetry test [60] using SPSS (Version 22.0, IBM, Armonk, NY, USA). Statistical significance was set at $p<0.05$. All analyses were conducted using RevMan 5 software (Version 5.3, The Nordic Cochrane Centre, Copenhagen, Denmark).

\section{Results}

\subsection{Selection Process of Studies}

Figure 1 illustrates the flowchart of the selection process of studies. Through electronic and manual literature searches, we identified a total of 289 articles and removed any duplicates. We then reviewed the titles and abstracts of 83 studies to assess their eligibility, of which 26 were considered relevant to this study and thus underwent full-text assessment (Figure 1). The final sample comprised six RCTs [31,32,61-64] published between 2013 and 2019. All of the six RCTs were included in the qualitative synthesis, and five of them were included in the meta-analysis [31,32,61-63].

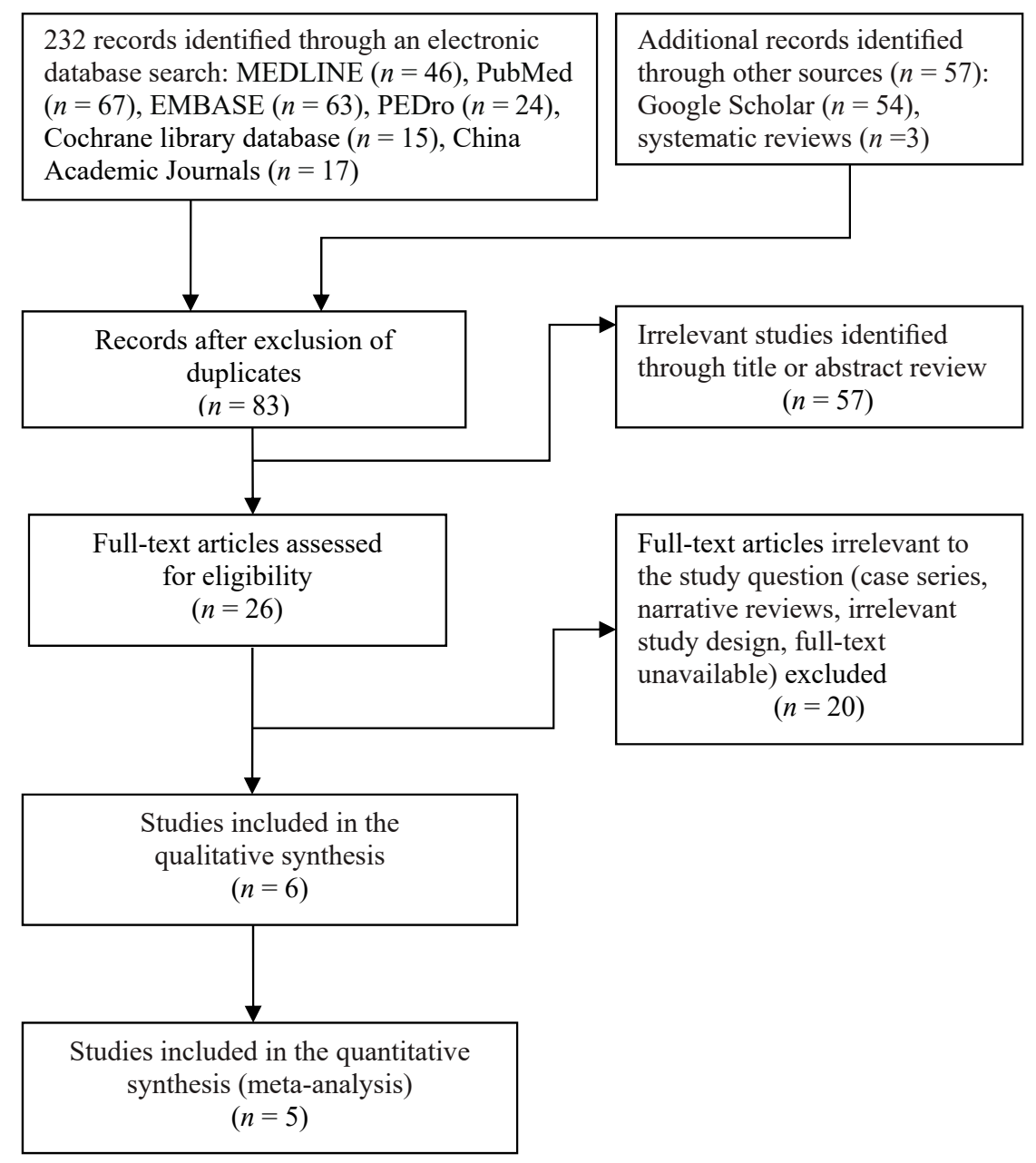

Figure 1. Flowchart of enrollment of the studies.

\subsection{Study Characteristics}

Table 1 summarizes the study characteristics and patient demographics of the included RCTs. The RCTs recruited a total of 242 participants with a mean age of 66.9 years (range: 63.6-75.6 years) and mean BMI of $28.1 \mathrm{~kg} / \mathrm{m}^{2}$ (range: $21.9-34.0 \mathrm{~kg} / \mathrm{m}^{2}$ ); $53.0 \%$ of the participants were female (range: $52.6 \%-77.3 \%$ ), which was estimated after excluding two sex-specific (women-only) RCTs [32,64]. 
Table 1. Characteristics of the included studies.

\begin{tabular}{|c|c|c|c|c|c|c|c|c|c|c|}
\hline \multirow[b]{2}{*}{$\begin{array}{l}\text { Study (Author, } \\
\text { Year, ref) }\end{array}$} & \multirow[b]{2}{*}{ Group $^{a}$} & \multirow[b]{2}{*}{$\mathbf{N}$} & \multirow[b]{2}{*}{ Design } & \multirow[b]{2}{*}{$\begin{array}{l}\text { Patient } \\
\text { Type }\end{array}$} & \multicolumn{2}{|c|}{ Exercise Intervention } & \multicolumn{2}{|c|}{ Dietary Intervention } & \multirow[b]{2}{*}{$\begin{array}{l}\text { Measured Time } \\
\text { Point }\end{array}$} & \multirow[b]{2}{*}{ Outcome Results } \\
\hline & & & & & $\begin{array}{l}\text { Type, } \\
\text { (Compliance: } \\
\text { \%, EG/CG) }^{\mathrm{b}}\end{array}$ & $\begin{array}{l}\text { Frequency } \times \\
\text { Duration }\end{array}$ & $\begin{array}{l}\text { Mode, Type } \\
\text { (Compliance: } \\
\%, \text { EG/CG) }\end{array}$ & $\begin{array}{l}\text { PS Dose } \\
\text { (g/day or } \\
\text { g/session) }\end{array}$ & & \\
\hline Baldissarro, 2016 [63] & $\begin{array}{l}\text { EG: PS + ET } \\
\text { CG: PLA + ET }\end{array}$ & $\begin{array}{l}30 \\
30\end{array}$ & $\mathrm{RCT}$ & THA & $\begin{array}{l}\text { PostOP MET } \\
\text { (NR) }\end{array}$ & $\begin{array}{l}2 \text { session } / \mathrm{d} \times 2 \mathrm{wk} \\
(24 \text { sessions) }\end{array}$ & $\begin{array}{l}\text { PS, EEA } \\
\text { (NR) }\end{array}$ & $8 \mathrm{~g} /$ day & $\begin{array}{l}\text { Baseline } \\
\text { Posttest: } 1,2,8,16 \mathrm{wk}\end{array}$ & $\begin{array}{l}\text { Harris Hip Score } \\
\text { CRP }\end{array}$ \\
\hline Dreyer, 2013 [31] & $\begin{array}{l}\text { EG: PS + ET } \\
\text { CG: PLA + ET }\end{array}$ & $\begin{array}{l}16 \\
12\end{array}$ & $\begin{array}{l}\mathrm{RCT} \\
\mathrm{DB}\end{array}$ & TKA & $\begin{array}{l}\text { PostOP MET } \\
\text { (NR) }\end{array}$ & $\begin{array}{l}2 \text { session } / \mathrm{d} \times 2 \mathrm{wk} \\
(24 \text { sessions })\end{array}$ & $\begin{array}{l}\text { PS, EAA } \\
\text { (NR) }\end{array}$ & $40 \mathrm{~g} /$ day & $\begin{array}{l}\text { Baseline } \\
\text { Posttest: } 3 \mathrm{wk} \\
\text { Follow-up: } 7 \mathrm{wk}\end{array}$ & $\begin{array}{l}\text { Qd volume } \\
\text { Qd strength; PA } \\
\text { TUG; SC; 6MWD }\end{array}$ \\
\hline Dreyer, 2018 [61] & $\begin{array}{l}\text { EG: PS + ET } \\
\text { CG: PLA + ET }\end{array}$ & $\begin{array}{l}19 \\
20\end{array}$ & $\begin{array}{l}\mathrm{RCT} \\
\mathrm{DB}\end{array}$ & TKA & $\begin{array}{l}\text { PostOP MET } \\
\text { (NR) }\end{array}$ & $\begin{array}{l}2 \text { session } / \mathrm{d} \times 2 \mathrm{wk} \\
(24 \text { sessions) }\end{array}$ & $\begin{array}{l}\text { PS, EAA } \\
\text { (NR) }\end{array}$ & $40 \mathrm{~g} /$ day & $\begin{array}{l}\text { Baseline } \\
\text { Posttest: } 3 \mathrm{wk} \\
\text { Follow-up: } 7 \mathrm{wk}\end{array}$ & $\begin{array}{l}\text { Qd strength; CRP } \\
\text { Qd volume; SC; GS } \\
\text { TUG; SF-36 PF; PA }\end{array}$ \\
\hline Ikeda, 2018 [64] & $\begin{array}{l}\text { EG: PS + ET } \\
\text { CG: PLA + ET }\end{array}$ & $\begin{array}{l}21 \\
22\end{array}$ & $\begin{array}{l}\text { RCT } \\
\text { SB }\end{array}$ & $\begin{array}{l}\text { Hip } \\
\text { OA }\end{array}$ & $\begin{array}{l}\text { RET } \\
(85.0 / 88.2)\end{array}$ & $\begin{array}{l}7 \mathrm{~d} / \mathrm{wk} \times 4 \mathrm{wk} \\
(28 \text { sessions })\end{array}$ & $\begin{array}{l}\text { PS, BCAA } \\
(83.4 / 92.0)\end{array}$ & $6.0 \mathrm{~g} / \mathrm{session}$ & $\begin{array}{l}\text { Baseline } \\
\text { Posttest: } 4 \mathrm{wk}\end{array}$ & $\begin{array}{l}\text { GS } \\
\text { Hip strength }\end{array}$ \\
\hline Ikeda, 2019 [32] & $\begin{array}{l}\text { EG: PS + ET } \\
\text { CG: PLA + ET }\end{array}$ & $\begin{array}{l}18 \\
13\end{array}$ & $\begin{array}{l}\mathrm{RCT} \\
\mathrm{SB}\end{array}$ & THA & $\begin{array}{l}\text { PostOP MET } \\
\text { (NR) }\end{array}$ & $\begin{array}{l}2 \text { session } / \mathrm{d} \times 4 \mathrm{wk} \\
(56 \text { sessions) }\end{array}$ & $\begin{array}{l}\text { PS, BCAA } \\
(100 / 100)\end{array}$ & $3.0 \mathrm{~g} /$ session & $\begin{array}{l}\text { Baseline } \\
\text { Posttest: HIDC }\end{array}$ & $\begin{array}{l}\text { Upper arm CSA } \\
\text { Qd strength }\end{array}$ \\
\hline Muyskens, 2019 [62] & $\begin{array}{l}\text { EG: PS + ET } \\
\text { CG: PLA + ET }\end{array}$ & $\begin{array}{l}19 \\
22\end{array}$ & $\begin{array}{l}\mathrm{RCT} \\
\mathrm{DB}\end{array}$ & TKA & $\begin{array}{l}\text { PostOP MET } \\
\text { (NR) }\end{array}$ & $\begin{array}{l}2-3 \mathrm{~d} / \mathrm{wk} \times 7 \mathrm{wk} \\
(21 \text { sessions })\end{array}$ & $\begin{array}{l}\text { PS, EAA } \\
(99 / 96)\end{array}$ & $40.0 \mathrm{~g} /$ day & $\begin{array}{l}\text { Baseline } \\
\text { Mid-test: 2,3 wk } \\
\text { Posttest: } 7 \mathrm{wk}\end{array}$ & $\begin{array}{l}\text { Number of myo- } \\
\text { fibers (Qd) } \\
\text { IL-6; TNF- } \alpha\end{array}$ \\
\hline
\end{tabular}

${ }^{a}$ All parallels of experimental and control groups are presented for each trial. ${ }^{\mathrm{b}}$ Values denote the compliance of interventions (\%). 6MWD, 6-min walk-for-distance; BCAA, branched chain amino acids; CG, control group; CSA, cross-sectional area; DB, double blind; EAA, essential amino acids; EG, experimental group; ET, exercise training; GS, gait speed; HIDC, hospital inpatient discharge; IL-6, interleukin-6; MET, multicomponent exercise training; NR, not reported; PA, physical activity; PLA, placebo supplement; PS, protein supplementation; Qd, quadriceps muscle; RCT, randomized controlled trial; ref, reference number; RET, resistance exercise training; SB, single blind; SC, stair climbing; SF-36 PF, Short-Form 36-Item Health Survey physical function subscore; TKA, total knee arthroplasty; TNF- $\alpha$, tumor necrosis factor- $\alpha$; THA, total hip arthroplasty; TUG, timed up and go test; wk week. 
Among all participants, 123 (50.8\%) received PS + ET, and 119 (49.2\%) received ET with placebo PS. In addition, $112(46.3 \%)$ patients enrolled in three RCTs received a diagnosis of knee OA and underwent total knee replacement (TKR) [31,61,62]. Furthermore, three RCTs enrolled 130 (53.7\%) older adults with a diagnosis of hip OA [32,63,64], of which two RCTs enrolled patients who underwent total hip replacement (THR) [32,63]. All the included RCTs enrolled patients who had OA with a K-L grade of III or IV, which was classified as moderate or severe OA, respectively [42].

Regarding the duration of follow-up for measuring outcomes, all included RCTs had short-term follow-up ( $\leq 1$ month), and four RCTs had medium-term follow-up (follow-up duration in these four RCTs: 7-16 weeks) [31,61-63]. None of the included RCTs reported long-term follow-up ( $\geq 6$ months).

\subsection{Protein Supplementation Characteristics}

Protocols for PS are summarized in Table 1. The protocols for PS, including additional PS, are detailed in Supplementary Table S2. The protocol for the protein nutrient intervention varied widely across the included RCTs. Among the six included RCTs, four prescribed essential amino acids, such as leucine [31,61-63], and two prescribed branched chain amino acids [32,64] at a supplement dose of 3.0-6.0 g/session or 8.0-40.0 g/day. In particular, in five RCTs, PS interventions were administered to patients who received total joint replacement [31,32,61-63], with an intervention period of 2-7 weeks after surgery (Supplementary Table S2).

\subsection{Exercise Training Protocol}

The ET protocols are summarized in Table 1 and detailed in Supplementary Table S3. Regarding the training mode of exercise, one of the six RCTs used preoperative home-based RET for older women with OA who were scheduled to undergo primary unilateral total hip arthroplasty [64], and in the other five RCTs, postoperative physical therapy in combination with MET was provided to patients who underwent TKR or THR. All the included RCTs employed short-term treatment (2-7 weeks over 21-56 sessions), and none of the included RCTs employed long-term treatment ( $\geq 6$ months).

\subsection{Risk of Bias of Included Studies}

The PEDro scores for individual studies are listed in Supplementary Table S4. Overall, three of the six included RCTs had high methodological quality [32,63,64], and the other three had medium methodological quality [31,61,62]; the median PEDro score was 6 (range: 6-9). The inter-rater reliability of the cumulative PEDro scores was acceptable, with an intraclass correlation coefficient of 0.97 (95\% CI: 0.82-0.99). All the included RCTs had the PEDro methodological features of random allocation, similarity at the baseline, between-group comparisons, and point estimates and variability. However, all the three RCTs with high quality $[32,63,64]$ employed allocation concealment in their methodology, but none of the RCTs with medium quality did. Furthermore, because of the nature of the interventions, therapist blinding was not plausible in some RCTs—although all RCTs with high and medium quality incorporated participant blinding into their PS intervention. In addition, assessor blinding was conducted in one [63] and three $[31,61,62]$ of RCTs with high and medium quality, respectively.

\subsection{Treatment Outcomes for Muscle Mass}

Muscle mass outcomes were investigated by measuring mid-thigh muscle CSA [62], upper-arm muscle CSA [32], and mid-thigh muscle volume [31,61] (Table 1). Two RCTs measured quadriceps and hamstring muscle volumes in both the involved (i.e., operative) and contralateral uninvolved (i.e., nonoperative) legs, respectively, in patients who underwent primary unilateral TKR $[31,61]$. The combined analysis demonstrated that over medium-term follow-up, PS + ET significantly increased quadriceps muscle volume in both the involved leg (weighted $\mathrm{MD}=7.38 \%, p<0.0001$; $I^{2}=71 \%$; Supplementary Figure S1a) and uninvolved leg (weighted MD $=6.11 \%, p=0.0002$; $I^{2}=0 \%$; Supplementary Figure S1b). Similarly, over medium-term follow-up duration, PS + ET improved hamstring muscle volume in both the operative leg (weighted $\mathrm{MD}=7.71 \%, p<0.00001$; 
$I^{2}=65 \%$; Supplementary Figure S2a) and uninvolved leg (weighted MD $=6.08 \%, p<0.0001 ; I^{2}=0 \%$; Supplementary Figure S2b).

One included RCT assessed changes in upper-arm CSA resulting from PS + ET administered after THR surgery [32]; according to its results, over short-term follow-up, PS + ET prevented postoperative upper-arm muscle atrophy, with an MD of $1.4 \mathrm{~cm}^{2}(p<0.05$; Supplementary Figure S3a). Similarly, one other included RCT investigated changes in the number of quadriceps myofibers resulting from PS + ET administered after TKR surgery [62]; according to its results, over short-term follow-up, PS + ET significantly improved the number of such myofibers in the uninvolved leg (MD = 19.8, $p<0.01$ ) but not the involved leg (Supplementary Figure S3b).

When all the muscle mass measures were pooled in this meta-analysis, the results indicated that PS + ET yielded significant improvements to muscle mass (SMD = 1.13, 95\% CI: 0.72-1.53, $p<0.00001$; $I^{2}=0 \%$ ), favoring PS + ET for all follow-up durations (Figure 2).

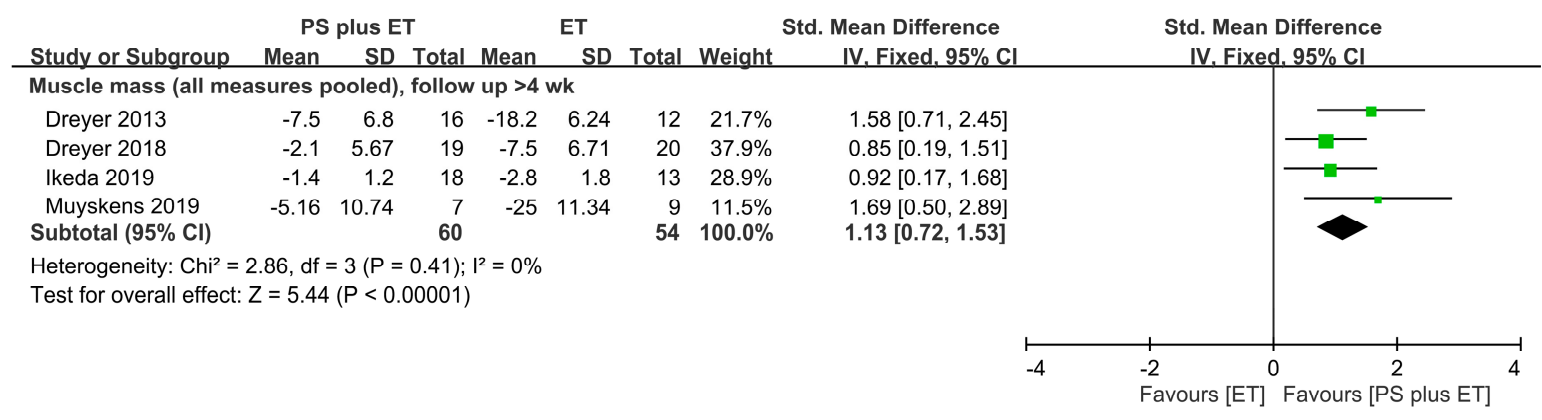

Figure 2. Forest plot summarizing the effects of postoperative protein supplementation (PS) plus exercise training (ET) on changes in muscle mass over medium-term follow-up. The square represents the point estimate of the intervention effect for each trial. The horizontal line links the lower and upper limits of the $95 \%$ CI for the given effect. The area of the squares indicates the relative weight of the trials in the meta-analysis. Trial results plotted on the right-hand side of the vertical axis indicate effects in favor of protein supplementation. The combined effects are plotted using black diamonds. 95\% CI, 95\% confidence interval; Std, standard; IV, inverse variance.

\subsection{Pain-Related Treatment Outcomes}

Pain outcomes were assessed using perceived-reported scales, which included the HHS pain subscale in one RCT [63] and the KOOS pain subscale in another RCT [61] (Table 1). The combined analysis revealed that PS + ET significantly reduced pain: the SMD of 1.36 (95\% CI: 0.68-2.03, $p<0.00001$; $I^{2}=54 \%$ ) was significant for the overall follow-up durations (Figure 3).

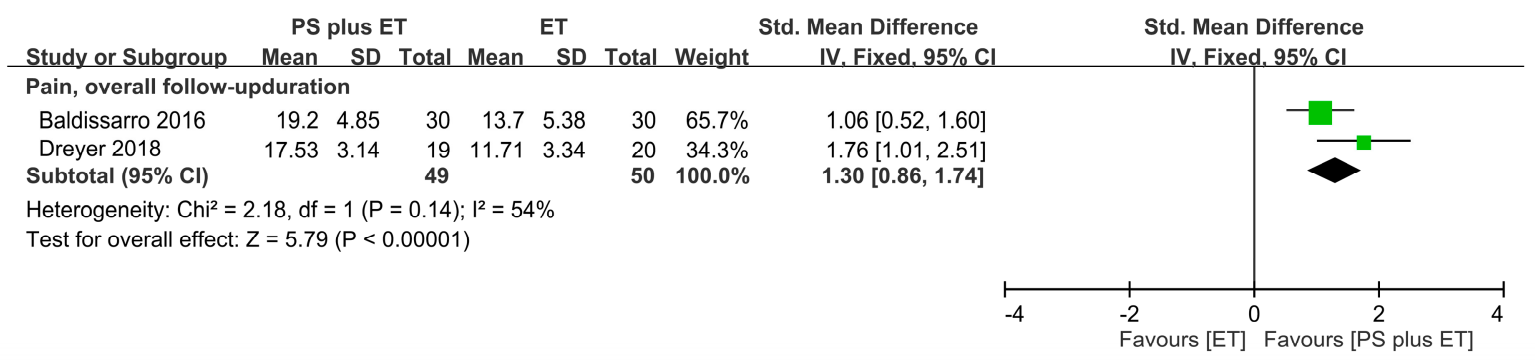

Figure 3. Forest plot summarizing the effects of postoperative protein supplementation (PS) plus exercise training (ET) on changes in the pain score over the overall follow-up period. The square represents the point estimate of the intervention effect for each trial. The horizontal line links the lower and upper limits of the $95 \%$ CI for the given effect. The area of the squares indicates the relative weight of the trials in the meta-analysis. Trial results plotted on the right-hand side of the vertical axis indicate effects in favor of protein supplementation. The combined effects are plotted using black diamonds. 95\% CI, 95\% confidence interval; Std, standard; IV, inverse variance. 


\subsection{Treatment Outcomes for Muscle Strength}

Three RCTs reported that PS + ET administered after total joint replacement improved lower-limb strength $[31,32,61]$ (Table 1). The meta-analysis results revealed that over the overall follow-up period, PS + ET improved muscle strength in both the involved leg $\left(\mathrm{SMD}=0.44, p=0.04 ; I^{2}=52 \%\right.$; Figure $\left.4 \mathrm{~A}\right)$ and the uninvolved leg (SMD $=0.54, p=0.01 ; I^{2}=0 \%$; Figure $\left.4 \mathrm{~B}\right)$. One RCT administered PS in combination with home-based RET for older women with hip OA during their waiting period for primary unilateral THR [64]; according to its results, PS + ET significantly improved hip abductor muscle strength in the unaffected leg (MD $=16.8 \%, p<0.01)$ but not the affected leg (Supplementary Figure S4).

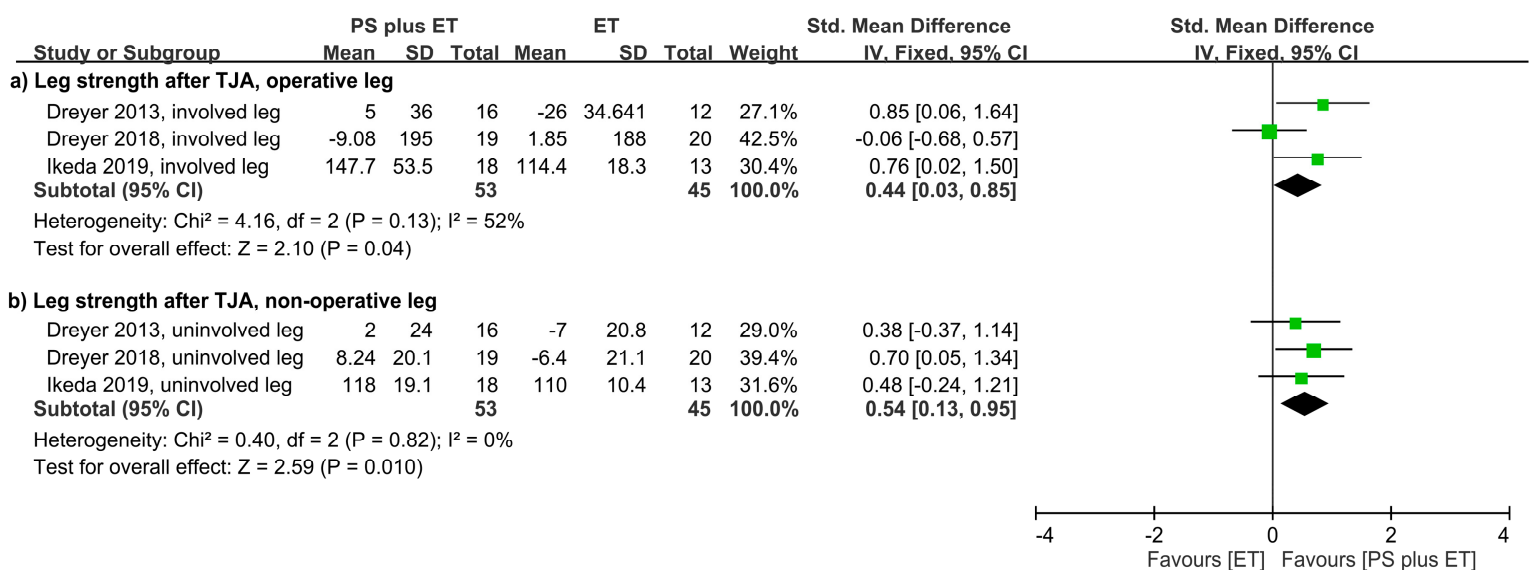

Figure 4. Forest plot summarizing the effects of postoperative protein supplementation (PS) plus exercise training (ET) on changes in muscle strength of (a) the involved leg and (b) the contralateral uninvolved leg over the overall follow-up period. The square represents the point estimate of the intervention effect for each trial. The horizontal line links the lower and upper limits of the $95 \%$ CI for the given effect. The area of the squares indicates the relative weight of the trials in the meta-analysis. Trial results plotted on the right-hand side of the vertical axis indicate effects in favor of protein supplementation. The combined effects are plotted using black diamonds. 95\% CI, 95\% confidence interval; Std, standard; IV, inverse variance; TJA, total joint arthroplasty.

\subsection{Treatment Outcomes Related to Physical Mobility and Physical Activity}

Postoperative physical mobility was assessed for patients who underwent total joint replacement. Such assessment was based on several performance-based functional activity tasks, including walking capability tests in three RCTs [31,61,64], timed up-and-go tests in two RCTs [31,61], and stair climb tests in two RCTs [31,61] (Table 1). The meta-analysis revealed that over the overall follow-up durations, PS + ET improved walking capability (SMD $=0.75, p=0.003 ; I^{2}=0 \%$; Figure 5a), timed up-and-go performance $\left(\mathrm{SMD}=0.66, p=0.01 ; I^{2}=0 \%\right.$; Figure $5 \mathrm{~b}$ ), and stair climbing performance $(\mathrm{SMD}=0.84$, $p=0.002 ; I^{2}=4 \%$; Figure $5 \mathrm{c}$ ). One RCT analyzed the $10-\mathrm{m}$ walk time before and after PS + ET for older women with hip OA who did not receive THR [64]; the results revealed that the improvement rate of walking capability nonsignificantly differed between the PS + ET and control groups (Supplementary Figure S5).

Over medium-term follow-up, postoperative physical activity was measured in terms of daily energy expenditure in one RCT [61] and daily step count in another RCT [31]. The meta-analysis revealed that PS + ET nonsignificantly improved physical activity (Figure 5d). 


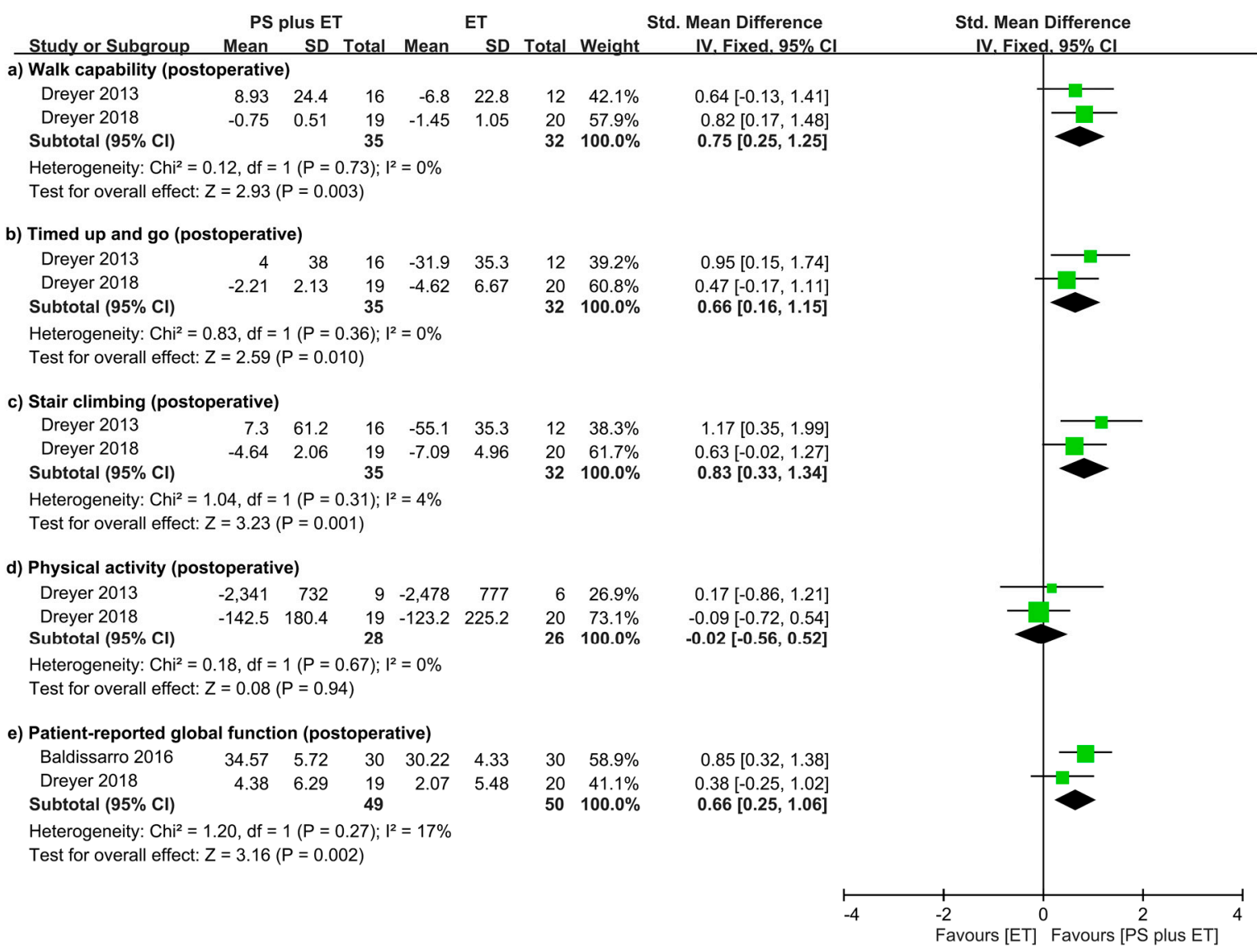

Figure 5. Forest plot summarizing the effects of postoperative protein supplementation (PS) plus exercise training (ET) on changes in (a) walking capability; (b) timed up-and-go performance; (c) stair climbing performance; (d) physical activity; and (e) global functioning over the overall follow-up period. The square represents the point estimate of the intervention effect for each trial. The horizontal line links the lower and upper limits of the $95 \%$ CI for the given effect. The area of the squares indicates the relative weight of the trials in the meta-analysis. Trial results plotted on the right-hand side of the vertical axis indicate effects in favor of protein supplementation. The combined effects are plotted using black diamonds. 95\% CI, 95\% confidence interval; Std, standard; IV, inverse variance.

\subsection{Treatment Outcomes in Patient-Reported Global Functioning}

In total, two of the included RCTs reported global functional outcomes that were assessed using self-perception questionnaires: the HHS in one RCT [63] and the SF-36 physical function subscale in the other RCT [61] (Table 1). An analysis of the combined results from the RCTs revealed that PS + ET provided significantly greater improvements to global functioning relative to the control intervention: the SMD was 0.65 (95\% CI: $\left.0.20-1.10, p=0.004 ; I^{2}=17 \%\right)$, regardless of the involved joint and follow-up duration (Figure 5e).

\subsection{Treatment Outcomes for Inflammatory Factors}

Systemic concentrations of proinflammatory cytokines were measured; concentrations of CRP, IL-6, and TNF- $\alpha$ were measured in two RCTs [61,63], one RCT [62], and one RCT [62], respectively (Table 1). The meta-analysis revealed that PS + ET improved CRP outcomes (weighted MD $=0.16 \mathrm{mg} / \mathrm{L}$, $p=0.04 ; I^{2}=0 \%$; Supplementary Figure S6). Furthermore, changes in IL-6 and TNF- $\alpha$ levels did not significantly differ between the PS + ET and control groups (Supplementary Figure S7).

When all the reported inflammatory measures were pooled in the meta-analysis, the results revealed an SMD of 0.37 (95\% CI: 0.03-0.70, $p=0.03 ; I^{2}=0 \%$ ), favoring PS + ET, regardless of the follow-up period (Figure 6). 


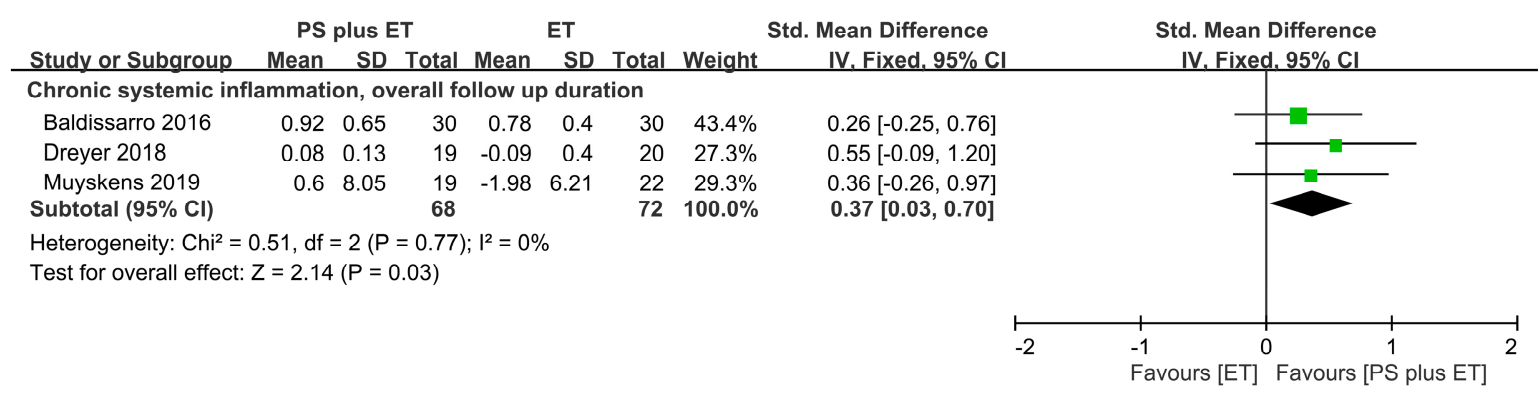

Figure 6. Forest plot summarizing the effects of postoperative protein supplementation (PS) plus exercise training (ET) on changes in systemic inflammation level during an overall follow-up duration. For each trial, the square represents the point estimate of the intervention effect. The horizontal line links the lower and upper limits of the $95 \%$ CI of this effect. The area of the squares reflects the relative weight of the trials in the meta-analysis. Trial results plotted on the right-hand side of the vertical axis indicate effects in favor of protein supplementation. The combined effects are plotted using black diamonds. 95\% CI, 95\% confidence interval; Std, standard; IV, inverse variance.

\subsection{Side Effects and Compliance}

All the included RCTs reported no clinically relevant adverse events, side effects, or major complications after the ET or PS intervention. Compliance to RET was reported to be $85.0 \%-88.2 \%$ in one RCT [64], and no RCT reported the compliance or attendance rate for MET sessions (Table 1). Compliance to PS was reported to be $83.4 \%-100 \%$ in three RCTs [32,62,64] (Table 1).

\subsection{Publication Bias}

The funnel plots of the effect sizes of each of the primary and secondary outcome measures are presented in Supplementary Figure S8. For all measures, visual evaluation of their funnel plots revealed no substantial asymmetry. A subsequent Egger's linear regression test also indicated no obvious reporting bias among the comparisons for all measures $(p>0.05)$.

\section{Discussion}

This study demonstrated that (1) PS + ET significantly improves muscle mass, muscle strength, and pain outcomes in older adults with lower-extremity OA, regardless of the follow-up duration, and that (2) PS + ET significantly improves secondary clinical outcomes, including physical mobility, systemic inflammation, and patient-reported global functioning. Subgroup analyses were not performed because all outcome measures exhibited no significant heterogeneity.

Previous systematic reviews and meta-analyses have investigated the effects of PS + ET on muscle mass outcomes in older adults who either were frail or had sarcopenia; these studies have reported-relative to ET alone-overall effects of PS + ET on the weighted MDs of lean mass gain ranging from 0.41 to $1.60 \mathrm{~kg}$ [29,65] or SMDs ranging from 0.23 to 2.05 [38,66-69] (Table 2). The present meta-analysis noted that PS + ET exerted greater effects on changes in muscle mass (SMD = 1.13) relative to the control; this finding indicates that PS + ET reverses or prevents the loss of muscle mass in older adults with OA. Our findings support the urgent necessity of incorporating protein-based nutrition or dietary intervention into ET to prevent functional decline in older adults with OA at risk of sarcopenia; this intervention is especially urgent for such older adults who have recently undergone total knee or hip replacement. This recommendation agrees with previous systematic reviews and with recommendations proposed by the European Society for Clinical Nutrition and Metabolism Expert Group [70]. 
Table 2. Meta-analysis results for effects of protein supplementation plus exercise on muscle mass in older adults.

\begin{tabular}{|c|c|c|c|c|c|c|}
\hline \multirow{3}{*}{$\begin{array}{l}\text { Study (Author, } \\
\text { Year, Reference) }\end{array}$} & \multirow{2}{*}{\multicolumn{2}{|c|}{ Participant Characteristics }} & \multicolumn{3}{|c|}{ Intervention Design } & \multirow{3}{*}{$\begin{array}{c}\text { Outcome (favoring PS + ET) } \\
\text { Muscle Mass }^{a}\end{array}$} \\
\hline & & & \multicolumn{2}{|c|}{ EG (PS + ET) } & \multirow{2}{*}{$\begin{array}{c}\text { CG } \\
\text { Comparison }\end{array}$} & \\
\hline & Population & Age (years) & ET & PS & & \\
\hline Finger, 2015 [67] & Sarcopenia & $60-79$ & $\begin{array}{l}\text { RET, } 2-3 \text { days/week, } \\
12-72 \text { weeks }\end{array}$ & $\begin{array}{l}\text { Whey, milk protein, } \\
\text { EAA (6-40 g/day) }\end{array}$ & $\begin{array}{l}\text { RET alone or with } \\
\text { placebo supplement }\end{array}$ & FFM: SMD = $0.23(0.05,0.42)$ \\
\hline Liao, 2017 [38]; 2018 [69] & $\begin{array}{l}\text { Overweight and } \\
\text { obesity; sarcopenia }\end{array}$ & $60-85$ & $\begin{array}{l}\text { RET, } 2-7 \text { days/week, } \\
12-24 \text { weeks }\end{array}$ & $\begin{array}{l}\text { Whey, leucine } \\
\text { (10-35 g/day) }\end{array}$ & $\begin{array}{l}\text { RET alone or with } \\
\text { placebo supplement }\end{array}$ & LBM: SMD = $0.52(0.18,0.85)$ \\
\hline Luo, 2017 [66] & Sarcopenia & $65-80$ & $\begin{array}{l}\text { RET or MET, } 2-3 \\
\text { days/week, } \\
12-16 \text { weeks }\end{array}$ & $\begin{array}{l}\text { Whey }(20-40 \mathrm{~g} / \text { day }) \\
\text { EAA }(6-17 \mathrm{~g} / \text { day })\end{array}$ & ET alone & $\begin{array}{l}\text { FFM: SMD }=5.78(5.17,6.40) \\
\text { LBM: SMD }=2.05(0.91,3.19)\end{array}$ \\
\hline Hidayat, 2018 [29] & Chronic conditions & $60-80$ & $\begin{array}{l}\text { RET, } 3-5 \text { days/week, } \\
12-72 \text { weeks }\end{array}$ & $\begin{array}{l}\text { Whey, milk protein } \\
(13-40 \mathrm{~g} / \text { day })\end{array}$ & $\begin{array}{l}\text { RET with placebo PS or } \\
\text { low-protein diet }\end{array}$ & FFM: WMD = $1.60(0.92,2.28) \mathrm{kg}$ \\
\hline Hita-Contreras, 2018 [65] & $\begin{array}{l}\text { Sarcopenia and } \\
\text { obesity }\end{array}$ & $76-81$ & $\begin{array}{l}\text { RET, } 1-2 \text { days/week, } \\
12-26 \text { weeks }\end{array}$ & $\begin{array}{l}\text { Whey ( } 40 \mathrm{~g} / \text { day), EAA } \\
\text { (leucine, } 3 \mathrm{~g} / \text { day) }\end{array}$ & $\begin{array}{l}\text { Regular care } \\
\text { (non-ET, non-PS) }\end{array}$ & $\begin{array}{l}\text { ALM: WMD = } 0.41(0.68,0.65) \mathrm{kg} \\
\text { SMI: SMD = } 0.47(-0.1,1.04)\end{array}$ \\
\hline Liao, 2019 [68] & Sarcopenia or frailty & $64-89$ & $\begin{array}{l}\text { RET or MET: } 2-7 \\
\text { days/week, } \\
\text { 3-36 weeks }\end{array}$ & $\begin{array}{l}\text { Whey, milk protein, } \\
\text { EAA (3-40 g/day) }\end{array}$ & $\begin{array}{l}\text { ET alone (with or without } \\
\text { placebo supplement) }\end{array}$ & $\begin{array}{l}\text { LBM: SMD }=0.53(0.21,0.86) \\
\text { ALM: SMD }=0.40(-0.02,0.52)\end{array}$ \\
\hline Current study & Osteoarthritis & $63-76$ & $\begin{array}{l}\text { RET or MET: } 2-7 \\
\text { d/week, } 2-24 \text { weeks }\end{array}$ & $\begin{array}{l}\text { EAA, BCAA } \\
(3-40 \text { g/day) }\end{array}$ & $\begin{array}{l}\text { ET alone (with or without } \\
\text { placebo supplement) }\end{array}$ & Muscle mass: SMD $=1.13(0.72,1.53)$ \\
\hline
\end{tabular}

${ }^{a}$ Data are presented as WMD or SMD with 95\% confidence interval in parentheses. ALM, appendicular lean mass; BCAA, branched chain amino acids; CG, control group; EAA, essential amino acid; EG, experimental group; ET, exercise training; FFM, fat-free mass; LBM, lean body mass; MET, multicomponent exercise training; PS, protein supplementation; RET; resistance exercise training; SMD, standardized mean difference: SMI, skeletal mass index; WMD, weighted mean difference. 
The present study noted that in older adults with OA, PS + ET significantly improved muscle mass; this finding suggests that PS further augments muscle-mass increases from exercise interventions. This finding is consistent with those of previous systematic reviews on the effectiveness of PS + ET in sarcopenic or frail older adults $[38,68]$, regardless of exercise type. Some reasons potentially explain the findings of the present study. First, both PS (especially with leucine and whey protein [71,72]) and ET stimulate myoprotein synthesis in older adults [71,73,74]; such stimulation occurs despite delayed and diminished muscle protein anabolic responses to PS + ET in older adults relative to younger controls [75,76]. In addition, in response to PS, older men with sarcopenia show an elevated rate of muscle protein synthesis-at a level comparable to that of their healthy peers [74]. The rate of muscle protein synthesis is more significantly increased by PS + ET than by either ET alone [77] or PS alone $[78,79]$, which also explains the results of previous studies $[38,68]$. Second, muscle wasting or atrophy in OA is primarily mediated by pain as well as by OA-associated inflammation through the disease process [7]. Loss of muscle mass in chronic diseases is frequently associated with increased production of proinflammatory cytokines (such as TNF- $\alpha$ and IL-6) and acute-phase inflammatory proteins (such as CRP), all of which are inflammatory biomarkers of OA [43]. Proinflammatory cytokines act on muscle protein metabolism by not only activating catabolic pathways but also downregulating the anabolic pathways; accordingly, systemic inflammation is associated with decreased rates of myoprotein synthesis accompanied with enhanced protein degradation (i.e., muscle breakdown) [80]. Therefore, treatments that are aimed at reducing levels of systemic inflammation may increase the rate of muscle mass gain. The present study revealed that PS + ET had a favorable effect on the reduction of systemic inflammatory biomarker concentrations, which potentially explains the muscle mass outcomes in this study.

The use of an additional PS product may further increase lean mass in patients with OA; we surmise this because a recent meta-analysis indicated that muscle strengthening exercises benefit muscle hypertrophy and lean mass gain in patients with OA [81]. However, in contrast to the results of the present study, previous systematic reviews have noted nonsignificant effects of PS + ET (usually RET), relative to ET alone, on changes in muscle mass in older adults who mostly were healthy or without OA $[67,82,83]$. This inconsistency in results is attributable to the differences in study populations. Furthermore, the differences in findings between previous reviews and the present meta-analysis further confirm the conclusion in the literature that older people who have either sarcopenia alone or sarcopenia with additional medical conditions may more greatly benefit from PS + ET than their healthy peers do in terms of lean mass gain and physical performance [29,84]. Therefore, targeting muscle mass through PS + ET administration serves as a promising intervention for preserving independence in daily living activities and preventing disease progression in older adults with OA.

Our study has several limitations. First, because of the variation in PS regimes (with respect to protein source, supplied amounts, and timing of ingestion) and ET regimes (with respect to training duration and training volume), our study did not yield a definite conclusion regarding the effect of a specific type of PS or ET on muscle mass or strength gain. Second, some of our included trials had small sample sizes [31,32]; these studies' results have indicated no significant intervention effect on primary or secondary outcomes, which potentially diminished the overall effect size. Finally, none of the included RCTs reported long-term follow-up ( $\geq 6$ months) outcomes for muscle mass and functioning. Thus, future studies should determine the long-term effects of PS + ET over follow-up periods $\geq 6$ months.

\section{Conclusions}

This meta-analysis demonstrated that PS is effective as a nutritional intervention; it yields improvements in muscle mass and strength during postoperative rehabilitation (mostly in MET regimes) for older adults with lower-extremity OA who have undergone total joint replacement. Postoperative PS further reduces pain, increases physical mobility, and improves global functioning after 2-7 weeks 
of rehabilitative ET. Considering the small number of RCTs included in this meta-analysis, more future studies are required to more robustly determine the efficacy of PS + ET in this specific population. In addition, only one RCT enrolled patients without prosthesis in our meta-analysis; therefore, we could not definitively conclude that PS + ET is effective in older adults with OA who did not undergo total joint replacement. Thus, future studies on the effectiveness of PS + ET should focus on people with OA who have not undergone total joint replacement. The results elucidate nutritional and exercise interventions that benefit older adults with $\mathrm{OA}$, particularly those who have undergone total joint replacement. The results also facilitate the formulation of practical and interdisciplinary approaches to counteracting muscle loss and functional decline. Practitioners in geriatric care and in rehabilitation settings, such as clinics, hospitals, institutions, and communities, can use our findings as a reference. Nevertheless, to better identify more optimal supplementation protocols, our results must be further validated by additional studies with relatively large samples.

Supplementary Materials: The following are available online at http://www.mdpi.com/2072-6643/12/8/2422/s1. Table S1. Database search formulas; Table S2. Summary of protein supplementation protocols in the included studies; Table S3. Summary of exercise training protocols in the included studies; Table S4. Summary of methodological quality of the included studies; Figure S1. Forest plot summarizing the effects of postoperative protein supplementation (PS) plus exercise training (ET) on changes in quadriceps muscle volume of (a) the involved leg and (b) the contralateral uninvolved leg over medium-term follow-up; Figure S2. Forest plot summarizing the effects of postoperative protein supplementation (PS) plus exercise training (ET) on changes in hamstring muscle volume of (a) the involved leg and (b) the contralateral uninvolved leg over medium-term follow-up; Figure S3. Forest plot summarizing the effects of postoperative protein supplementation (PS) plus exercise training (ET) on changes in (a) upper-arm CSA and (b) number of quadriceps myofibers over the overall follow-up period; Figure S4. Forest plot summarizing the effects of protein supplementation (PS) plus exercise training (ET) on changes in hip abductor strength in patients who did not undergo total joint arthroplasty; Figure S5. Forest plot summarizing the effects of protein supplementation (PS) plus exercise training (ET) on changes in walking speed in patients who did not undergo total joint arthroplasty; Figure S6. Forest plot summarizing the effects of postoperative protein supplementation (PS) plus exercise training (ET) on changes in C-reactive protein over the overall follow-up period; Figure S7. Forest plot summarizing the effects of postoperative protein supplementation (PS) plus exercise training (ET) on changes in (a) interleukin- 6 and (b) TNF- $\alpha$ over short-term follow-up; Figure S8. Funnel plots of intervention effects for (a) muscle mass, (b) pain, and (c) muscle strength.

Author Contributions: Conceptualization and design of the experiments, C.D.L., Y.-T.W., and T.-H.L.; search and selection of relevant studies, C.-D.L., H.-C.C., and T.-H.L.; data extraction, C.-D.L., H.-C.C., and T.-H.L.; data analysis, C.-D.L. and H.-C.C.; manuscript preparation, C.-D.L. and T.-H.L.; review and verification of the paper, Y.-T.W., J.-Y.T., P.-R.C., Y.-K.T., and T.-H.L.; primary responsibility for the final content of the paper, C.-D.L., H.-C.C., and T.-H.L. All authors have read and agreed to the published version of the manuscript.

Funding: This study was funded by grants from Taipei Medical University-Shuang Ho Hospital, Ministry of Health and Welfare, Taiwan (grant no. 109TMU-SHH-13) and Taipei Medical University (grant no. IIT-1072-3). The APC was funded by Taipei Medical University. The funding source played no role in the design, implementation, data analysis, interpretation, or reporting of the study. The contents of this publication are solely the responsibility of the authors and do not necessarily represent the official view of the funding sources.

Acknowledgments: This manuscript was edited by Wallace Academic Editing.

Conflicts of Interest: The authors declare no conflict of interest to the publication of this article.

\section{References}

1. Lewis, R.; Gómez Álvarez, C.B.; Rayman, M.; Lanham-New, S.; Woolf, A.; Mobasheri, A. Strategies for optimising musculoskeletal health in the 21st century. BMC Musculoskelet. Disord. 2019, 20, 164. [CrossRef]

2. Hunter, D.J.; Bierma-Zeinstra, S. Osteoarthritis. Lancet 2019, 393, 1745-1759. [CrossRef]

3. Palazzo, C.; Ravaud, J.F.; Papelard, A.; Ravaud, P.; Poiraudeau, S. The burden of musculoskeletal conditions. PLoS ONE 2014, 9, e90633. [CrossRef] [PubMed]

4. Loureiro, A.; Constantinou, M.; Diamond, L.E.; Beck, B.; Barrett, R. Individuals with mild-to-moderate hip osteoarthritis have lower limb muscle strength and volume deficits. BMC Musculoskel. Disord. 2018, 19, 303. [CrossRef] [PubMed]

5. Taniguchi, M.; Fukumoto, Y.; Kobayashi, M.; Kawasaki, T.; Maegawa, S.; Ibuki, S.; Ichihashi, N. Quantity and Quality of the Lower Extremity Muscles in Women with Knee Osteoarthritis. Ultrasound Med. Biol. 2015, 41, 2567-2574. [CrossRef] [PubMed] 
6. Cruz-Jentoft, A.J.; Bahat, G.; Bauer, J.; Boirie, Y.; Bruyere, O.; Cederholm, T.; Cooper, C.; Landi, F.; Rolland, Y.; Sayer, A.A.; et al. Sarcopenia: Revised European consensus on definition and diagnosis. Age Ageing 2019, 48, 16-31. [CrossRef] [PubMed]

7. Shorter, E.; Sannicandro, A.J.; Poulet, B.; Goljanek-Whysall, K. Skeletal Muscle Wasting and Its Relationship with Osteoarthritis: A Mini-Review of Mechanisms and Current Interventions. Curr. Rheumatol. Rep. 2019, 21, 40. [CrossRef] [PubMed]

8. Lee, S.Y.; Ro, H.J.; Chung, S.G.; Kang, S.H.; Seo, K.M.; Kim, D.K. Low Skeletal Muscle Mass in the Lower Limbs Is Independently Associated to Knee Osteoarthritis. PLoS ONE 2016, 11, e0166385. [CrossRef]

9. Jeon, H.; Lee, S.U.; Lim, J.Y.; Chung, S.G.; Lee, S.J.; Lee, S.Y. Low skeletal muscle mass and radiographic osteoarthritis in knee, hip, and lumbar spine: A cross-sectional study. Aging Clin. Exp. Res. 2019, 31, 1557-1562. [CrossRef]

10. Davison, M.J.; Maly, M.R.; Keir, P.J.; Hapuhennedige, S.M.; Kron, A.T.; Adachi, J.D.; Beattie, K.A. Lean muscle volume of the thigh has a stronger relationship with muscle power than muscle strength in women with knee osteoarthritis. Clin. Biomech. 2017, 41, 92-97. [CrossRef]

11. Lee, J.S.; Auyeung, T.W.; Kwok, T.; Lau, E.M.; Leung, P.C.; Woo, J. Associated factors and health impact of sarcopenia in older chinese men and women: A cross-sectional study. Gerontology 2007, 53, 404-410. [CrossRef] [PubMed]

12. Janssen, I.; Heymsfield, S.B.; Ross, R. Low relative skeletal muscle mass (sarcopenia) in older persons is associated with functional impairment and physical disability. J. Am. Geriatr. Soc. 2002, 50, 889-896. [CrossRef] [PubMed]

13. Hawker, G.A. Osteoarthritis is a serious disease. Clin. Exp. Rheumatol. 2019, 37, 3-6. [PubMed]

14. Ariani, A.; Manara, M.; Fioravanti, A.; Iannone, F.; Salaffi, F.; Ughi, N.; Prevete, I.; Bortoluzzi, A.; Parisi, S.; Scire, C.A. The Italian Society for Rheumatology clinical practice guidelines for the diagnosis and management of knee, hip and hand osteoarthritis. Reumatismo 2019, 71, 5-21. [CrossRef] [PubMed]

15. Szychlinska, M.A.; Castrogiovanni, P.; Trovato, F.M.; Nsir, H.; Zarrouk, M.; Lo Furno, D.; Di Rosa, M.; Imbesi, R.; Musumeci, G. Physical activity and Mediterranean diet based on olive tree phenolic compounds from two different geographical areas have protective effects on early osteoarthritis, muscle atrophy and hepatic steatosis. Eur. J. Nutr. 2019, 58, 565-581. [CrossRef] [PubMed]

16. Castrogiovanni, P.; Di Rosa, M.; Ravalli, S.; Castorina, A.; Guglielmino, C.; Imbesi, R.; Vecchio, M.; Drago, F.; Szychlinska, M.A.; Musumeci, G. Moderate Physical Activity as a Prevention Method for Knee Osteoarthritis and the Role of Synoviocytes as Biological Key. Int. J. Mol. Sci. 2019, 20, 511. [CrossRef]

17. Szychlinska, M.A.; Imbesi, R.; Castrogiovanni, P.; Guglielmino, C.; Ravalli, S.; Di Rosa, M.; Musumeci, G. Assessment of Vitamin D Supplementation on Articular Cartilage Morphology in a Young Healthy Sedentary Rat Model. Nutrients 2019, 11, 1260. [CrossRef]

18. Trovato, F.M.; Castrogiovanni, P.; Szychlinska, M.A.; Purrello, F.; Musumeci, G. Impact of Western and Mediterranean Diets and Vitamin D on Muscle Fibers of Sedentary Rats. Nutrients 2018, 10, 231. [CrossRef]

19. Musumeci, G. Sarcopenia and exercise "The State of the Art". J. Funct. Morphol. Kinesiol. 2017, 2, 40. [CrossRef]

20. Skou, S.T.; Roos, E.M. Physical therapy for patients with knee and hip osteoarthritis: Supervised, active treatment is current best practice. Clin. Exp. Rheumatol. 2019, 37, 112-117.

21. Castrogiovanni, P.; Di Giunta, A.; Guglielmino, C.; Roggio, F.; Romeo, D.; Fidone, F.; Imbesi, R.; Loreto, C.; Castorina, S.; Musumeci, G. The effects of exercise and kinesio tape on physical limitations in patients with knee osteoarthritis. J. Funct. Morphol. Kinesiol. 2016, 1, 355-368. [CrossRef]

22. Lo, J.H.; Uk, P.; Yiu, T.; Ong, M.T.; Lee, W.Y. Sarcopenia: Current treatments and new regenerative therapeutic approaches. J. Orthop. Translat. 2020, 23, 38-52. [CrossRef] [PubMed]

23. Miller, M.J.S.; Butler, R. Relief of osteoarthritis with an herbal-amino acid supplement: A randomized double-blind placebo controlled trial. Adv. Biosci. Biotechnol. 2012, 3, 504. [CrossRef]

24. Zenk, J.L.; Helmer, T.R.; Kuskowski, M.A. The effects of milk protein concentrate on the symptoms of osteoarthritis in adults: An exploratory, randomized, double-blind, placebo-controlled trial. Curr. Ther. Res. 2002, 63, 430-442. [CrossRef]

25. Colker, C.M.; Swain, M.; Lynch, L.; Gingerich, D.A. Effects of a milk-based bioactive micronutrient beverage on pain symptoms and activity of adults with osteoarthritis: A double-blind, placebo-controlled clinical evaluation. Nutrition 2002, 18, 388-392. [CrossRef] 
26. De Zwart, A.H.; van der Leeden, M.; Roorda, L.D.; Visser, M.; van der Esch, M.; Lems, W.F.; Dekker, J. Dietary protein intake and upper leg muscle strength in subjects with knee osteoarthritis: Data from the osteoarthritis initiative. Rheumatol. Int. 2019, 39, 277-284. [CrossRef]

27. Purcell, S.; Thornberry, R.; Elliott, S.A.; Panton, L.; Ormsbee, M.J.; Vieira, E.R.; Kim, J.S.; Prado, C.M. Body Composition, Strength, and Dietary Intake of Patients with Hip or Knee Osteoarthritis. Can. J. Diet Pract. Res. 2016, 77, 98-102. [CrossRef]

28. Woo, J. Nutritional interventions in sarcopenia: Where do we stand? Curr. Opin. Clin. Nutr. Metab. Care 2018, 21, 19-23. [CrossRef]

29. Hidayat, K.; Chen, G.-C.; Wang, Y.; Zhang, Z.; Dai, X.; Szeto, I.M.Y.; Qin, L.-Q. Effects of milk proteins supplementation in older adults undergoing resistance training: A meta-analysis of randomized control trials. J. Nutr. Health Aging 2018, 22, 237-245. [CrossRef]

30. Nishizaki, K.; Ikegami, H.; Tanaka, Y.; Imai, R.; Matsumura, H. Effects of supplementation with a combination of beta-hydroxy-beta-methyl butyrate, L-arginine, and L-glutamine on postoperative recovery of quadriceps muscle strength after total knee arthroplasty. Asia Pac. J. Clin. Nutr. 2015, 24, 412-420.

31. Dreyer, H.C.; Strycker, L.A.; Senesac, H.A.; Hocker, A.D.; Smolkowski, K.; Shah, S.N.; Jewett, B.A. Essential amino acid supplementation in patients following total knee arthroplasty. J. Clin. Investig. 2013, 123, 4654-4666. [CrossRef] [PubMed]

32. Ikeda, T.; Matsunaga, Y.; Kanbara, M.; Kamono, A.; Masuda, T.; Watanabe, M.; Nakanishi, R.; Jinno, T. Effect of exercise therapy combined with branched-chain amino acid supplementation on muscle strength in elderly women after total hip arthroplasty: A randomized controlled trial. Asia Pac. J. Clin. Nutr. 2019, 28, 720-726. [PubMed]

33. Dreyer, H.C. Tourniquet Use During Knee Replacement Surgery May Contribute to Muscle Atrophy in Older Adults. Exerc. Sport Sci. Rev. 2016, 44, 61-70. [CrossRef] [PubMed]

34. Kouw, I.W.K.; Groen, B.B.L.; Smeets, J.S.J.; Kramer, I.F.; van Kranenburg, J.M.X.; Nilwik, R.; Geurts, J.A.P.; ten Broeke, R.H.M.; Poeze, M.; van Loon, L.J.C.; et al. One Week of Hospitalization Following Elective Hip Surgery Induces Substantial Muscle Atrophy in Older Patients. J. Am. Med. Dir. Assoc. 2019, 20, 35-42. [CrossRef]

35. Petterson, S.C.; Barrance, P.; Marmon, A.R.; Handling, T.; Buchanan, T.S.; Snyder-Mackler, L. Time course of quad strength, area, and activation after knee arthroplasty and strength training. Med. Sci. Sports Exerc. 2011, 43, 225-231. [CrossRef]

36. Bennell, K.L.; Wrigley, T.V.; Hunt, M.A.; Lim, B.W.; Hinman, R.S. Update on the role of muscle in the genesis and management of knee osteoarthritis. Rheum. Dis. Clin. N. Am. 2013, 39, 145-176. [CrossRef]

37. Krishnasamy, P.; Hall, M.; Robbins, S.R. The role of skeletal muscle in the pathophysiology and management of knee osteoarthritis. Rheumatology 2018, 57, iv22-iv33. [CrossRef]

38. Liao, C.D.; Tsauo, J.Y.; Wu, Y.T.; Cheng, C.P.; Chen, H.C.; Huang, Y.C.; Chen, H.C.; Liou, T.H. Effects of protein supplementation combined with resistance exercise on body composition and physical function in older adults: A systematic review and meta-analysis. Am. J. Clin. Nutr. 2017, 106, 1078-1091. [CrossRef]

39. Liao, C.D.; Lee, P.H.; Hsiao, D.J.; Huang, S.W.; Tsauo, J.Y.; Chen, H.C.; Liou, T.H. Effects of Protein Supplementation Combined with Exercise Intervention on Frailty Indices, Body Composition, and Physical Function in Frail Older Adults. Nutrients 2018, 10, 1916. [CrossRef]

40. Morton, R.W.; Murphy, K.T.; McKellar, S.R.; Schoenfeld, B.J.; Henselmans, M.; Helms, E.; Aragon, A.A.; Devries, M.C.; Banfield, L.; Krieger, J.W.; et al. A systematic review, meta-analysis and meta-regression of the effect of protein supplementation on resistance training-induced gains in muscle mass and strength in healthy adults. Br. J. Sports Med. 2018, 52, 376-384. [CrossRef]

41. Shamseer, L.; Moher, D.; Clarke, M.; Ghersi, D.; Liberati, A.; Petticrew, M.; Shekelle, P.; Stewart, L.A. Preferred reporting items for systematic review and meta-analysis protocols (PRISMA-P) 2015: Elaboration and explanation. BMJ 2015, 349, g7647. [CrossRef] [PubMed]

42. Kellgren, J.H.; Lawrence, J.S. Radiological assessment of osteo-arthrosis. Ann. Rheum. Dis. 1957, 16, 494-502. [CrossRef] [PubMed]

43. Daghestani, H.N.; Kraus, V.B. Inflammatory biomarkers in osteoarthritis. Osteoarthr. Cartil. 2015, 23, 1890-1896. [CrossRef] 
44. Nilsdotter, A.; Bremander, A. Measures of hip function and symptoms: Harris Hip Score (HHS), Hip Disability and Osteoarthritis Outcome Score (HOOS), Oxford Hip Score (OHS), Lequesne Index of Severity for Osteoarthritis of the Hip (LISOH), and American Academy of Orthopedic Surgeons (AAOS) Hip and Knee Questionnaire. Arthr. Care Res. 2011, 63, S200-S207.

45. Kuo, A.C.; Giori, N.J.; Bowe, T.R.; Manfredi, L.; Lalani, N.F.; Nordin, D.A.; Harris, A.H.S. Comparing Methods to Determine the Minimal Clinically Important Differences in Patient-Reported Outcome Measures for Veterans Undergoing Elective Total Hip or Knee Arthroplasty in Veterans Health Administration Hospitals. JAMA Surg. 2020, e200024. [CrossRef]

46. McHorney, C.A.; Ware, J.E., Jr.; Raczek, A.E. The MOS 36-Item Short-Form Health Survey (SF-36): II. Psychometric and clinical tests of validity in measuring physical and mental health constructs. Med. Care 1993, 31, 247-263. [CrossRef]

47. Wu, C.H.; Chen, K.T.; Hou, M.T.; Chang, Y.F.; Chang, C.S.; Liu, P.Y.; Wu, S.J.; Chiu, C.J.; Jou, I.M.; Chen, C.Y. Prevalence and associated factors of sarcopenia and severe sarcopenia in older Taiwanese living in rural community: The Tianliao Old People study 04. Geriatr. Gerontol. Int. 2014, 14, 69-75. [CrossRef]

48. Tooth, L.; Bennett, S.; McCluskey, A.; Hoffmann, T.; McKenna, K.; Lovarini, M. Appraising the quality of randomized controlled trials: Inter-rater reliability for the OTseeker evidence database. J. Eval. Clin. Pract. 2005, 11, 547-555. [CrossRef]

49. Foley, N.C.; Bhogal, S.K.; Teasell, R.W.; Bureau, Y.; Speechley, M.R. Estimates of quality and reliability with the physiotherapy evidence-based database scale to assess the methodology of randomized controlled trials of pharmacological and nonpharmacological interventions. Phys. Ther. 2006, 86, 817-824. [CrossRef]

50. Briani, R.V.; Ferreira, A.S.; Pazzinatto, M.F.; Pappas, E.; De Oliveira Silva, D.; Azevedo, F.M. What interventions can improve quality of life or psychosocial factors of individuals with knee osteoarthritis? A systematic review with meta-analysis of primary outcomes from randomised controlled trials. Br. J. Sports Med. 2018, 52, 1031-1038. [CrossRef]

51. Cermak, N.M.; Res, P.T.; de Groot, L.C.; Saris, W.H.; van Loon, L.J. Protein supplementation augments the adaptive response of skeletal muscle to resistance-type exercise training: A meta-analysis. Am. J. Clin. Nutr. 2012, 96, 1454-1464. [CrossRef] [PubMed]

52. Ten Haaf, D.S.M.; Eijsvogels, T.M.H.; Bongers, C.C.W.G.; Horstman, A.M.H.; Timmers, S.; de Groot, L.C.P.G.M.; Hopman, M.T.E. Protein supplementation improves lean body mass in physically active older adults: A randomized placebo-controlled trial. J. Cachexia Sarcopenia Muscle 2019. [CrossRef]

53. Oesen, S.; Halper, B.; Hofmann, M.; Jandrasits, W.; Franzke, B.; Strasser, E.M.; Graf, A.; Tschan, H.; Bachl, N.; Quittan, M.; et al. Effects of elastic band resistance training and nutritional supplementation on physical performance of institutionalised elderly-A randomized controlled trial. Exp. Gerontol. 2015, 72, 99-108. [CrossRef] [PubMed]

54. Kim, H.; Kim, M.; Kojima, N.; Fujino, K.; Hosoi, E.; Kobayashi, H.; Somekawa, S.; Niki, Y.; Yamashiro, Y.; Yoshida, H. Exercise and Nutritional Supplementation on Community-Dwelling Elderly Japanese Women With Sarcopenic Obesity: A Randomized Controlled Trial. J. Am. Med. Dir. Assoc. 2016, 17, 1011-1019. [CrossRef] [PubMed]

55. Lai, C.C.; Tu, Y.K.; Wang, T.G.; Huang, Y.T.; Chien, K.L. Effects of resistance training, endurance training and whole-body vibration on lean body mass, muscle strength and physical performance in older people: A systematic review and network meta-analysis. Age Ageing 2018, 47, 367-373. [CrossRef]

56. Higgins, J.P.T.; Li, T.; Deeks, J.J. Chapter 6: Choosing effect measures and computing estimates of effect. In Cochrane Handbook for Systematic Reviews of Interventions, 6th ed.; Higgins, J.P.T., Ed.; The Cochrane Collaboration: London, UK, 2019.

57. Deeks, J.J.; Higgins, J.P.T.; Altman, D.G. Chapter 10: Analysing data and undertaking meta-analyses. In Cochrane Handbook for Systematic Reviews of Interventions, 6th ed.; Higgins, J.P.T., Ed.; The Cochrane Collaboration: London, UK, 2019.

58. Churchward-Venne, T.A.; Holwerda, A.M.; Phillips, S.M.; van Loon, L.J. What is the Optimal Amount of Protein to Support Post-Exercise Skeletal Muscle Reconditioning in the Older Adult? Sports Med. 2016, 46, 1205-1212. [CrossRef]

59. Sedgwick, P.; Marston, L. How to read a funnel plot in a meta-analysis. BMJ. 2015, 351, 1-3. [CrossRef]

60. Egger, M.; Davey Smith, G.; Schneider, M.; Minder, C. Bias in meta-analysis detected by a simple, graphical test. BMJ 1997, 315, 629-634. [CrossRef] 
61. Dreyer, H.C.; Owen, E.C.; Strycker, L.A.; Smolkowski, K.; Muyskens, J.B.; Kirkpatrick, T.K.; Christie, A.D.; Kuehl, K.S.; Lantz, B.A.; Shah, S.N.; et al. Essential Amino Acid Supplementation Mitigates Muscle Atrophy After Total Knee Arthroplasty: A Randomized, Double-Blind, Placebo-Controlled Trial. JB JS Open Access. 2018, 3, e0006. [CrossRef]

62. Muyskens, J.B.; Foote, D.M.; Bigot, N.J.; Strycker, L.A.; Smolkowski, K.; Kirkpatrick, T.K.; Lantz, B.A.; Shah, S.N.; Mohler, C.G.; Jewett, B.A.; et al. Cellular and morphological changes with EAA supplementation before and after total knee arthroplasty. J. Appl. Physiol. 2019, 127, 531-545. [CrossRef]

63. Baldissarro, E.; Aquilani, R.; Boschi, F.; Baiardi, P.; Iadarola, P.; Fumagalli, M.; Pasini, E.; Verri, M.; Dossena, M.; Gambino, A.; et al. The Hip Functional Retrieval after Elective Surgery May Be Enhanced by Supplemented Essential Amino Acids. Biomed. Res. Int. 2016, 2016, 9318329. [CrossRef] [PubMed]

64. Ikeda, T.; Jinno, T.; Masuda, T.; Aizawa, J.; Ninomiya, K.; Suzuki, K.; Hirakawa, K. Effect of exercise therapy combined with branched-chain amino acid supplementation on muscle strengthening in persons with osteoarthritis. Hong Kong Physiother. J. 2018, 38, 23-31. [CrossRef] [PubMed]

65. Hita-Contreras, F.; Bueno-Notivol, J.; Martinez-Amat, A.; Cruz-Diaz, D.; Hernandez, A.V.; Perez-Lopez, F.R. Effect of exercise alone or combined with dietary supplements on anthropometric and physical performance measures in community-dwelling elderly people with sarcopenic obesity: A meta-analysis of randomized controlled trials. Maturitas 2018, 116, 24-35. [CrossRef] [PubMed]

66. Luo, D.; Lin, Z.; Li, S.; Liu, S.-J. Effect of nutritional supplement combined with exercise intervention on sarcopenia in the elderly: A meta-analysis. Int. J. Nurs. Sci. 2017, 4, 389-401. [CrossRef]

67. Finger, D.; Goltz, F.R.; Umpierre, D.; Meyer, E.; Rosa, L.H.; Schneider, C.D. Effects of protein supplementation in older adults undergoing resistance training: A systematic review and meta-analysis. Sports Med. 2015, 45, 245-255. [CrossRef]

68. Liao, C.D.; Chen, H.C.; Huang, S.W.; Liou, T.H. The Role of Muscle Mass Gain Following Protein Supplementation Plus Exercise Therapy in Older Adults with Sarcopenia and Frailty Risks: A Systematic Review and Meta-Regression Analysis of Randomized Trials. Nutrients 2019, 11, 1713. [CrossRef]

69. Liao, C.D.; Tsauo, J.Y.; Chen, H.C.; Liou, T.H. Reply to RW Morton and SM Phillips. Am. J. Clin. Nutr. 2018, 107, 1056-1057. [CrossRef]

70. Deutz, N.E.; Bauer, J.M.; Barazzoni, R.; Biolo, G.; Boirie, Y.; Bosy-Westphal, A.; Cederholm, T.; Cruz-Jentoft, A.; Krznaric, Z.; Nair, K.S.; et al. Protein intake and exercise for optimal muscle function with aging: Recommendations from the ESPEN Expert Group. Clin. Nutr. 2014, 33, 929-936. [CrossRef]

71. Breen, L.; Phillips, S.M. Interactions between exercise and nutrition to prevent muscle waste during ageing. Br. J. Clin. Pharmacol. 2013, 75, 708-715. [CrossRef]

72. Dideriksen, K.J.; Reitelseder, S.; Petersen, S.G.; Hjort, M.; Helmark, I.C.; Kjaer, M.; Holm, L. Stimulation of muscle protein synthesis by whey and caseinate ingestion after resistance exercise in elderly individuals. Scand. J. Med. Sci. Sports 2011, 21, e372-e383. [CrossRef]

73. Bell, K.E.; Séguin, C.; Parise, G.; Baker, S.K.; Phillips, S.M. Day-to-Day Changes in Muscle Protein Synthesis in Recovery From Resistance, Aerobic, and High-Intensity Interval Exercise in Older Men. J. Gerontol. A Biol. Sci. Med. Sci. 2015, 70, 1024-1029. [CrossRef]

74. Kramer, I.F.; Verdijk, L.B.; Hamer, H.M.; Verlaan, S.; Luiking, Y.C.; Kouw, I.W.K.; Senden, J.M.; van Kranenburg, J.; Gijsen, A.P.; Bierau, J.; et al. Both basal and post-prandial muscle protein synthesis rates, following the ingestion of a leucine-enriched whey protein supplement, are not impaired in sarcopenic older males. Clin. Nutr. 2017, 36, 1440-1449. [CrossRef]

75. Drummond, M.J.; Dreyer, H.C.; Pennings, B.; Fry, C.S.; Dhanani, S.; Dillon, E.L.; Sheffield-Moore, M.; Volpi, E.; Rasmussen, B.B. Skeletal muscle protein anabolic response to resistance exercise and essential amino acids is delayed with aging. J. Appl. Physiol. 2008, 104, 1452-1461. [CrossRef]

76. Smeuninx, B.; McKendry, J.; Wilson, D.; Martin, U.; Breen, L. Age-Related Anabolic Resistance of Myofibrillar Protein Synthesis Is Exacerbated in Obese Inactive Individuals. J. Clin. Endocrinol. Metab. 2017, 102, 3535-3545. [CrossRef]

77. Trommelen, J.; Betz, M.W.; van Loon, L.J.C. The Muscle Protein Synthetic Response to Meal Ingestion Following Resistance-Type Exercise. Sports Med. 2019, 49, 185-197. [CrossRef]

78. Moore, D.R.; Tang, J.E.; Burd, N.A.; Rerecich, T.; Tarnopolsky, M.A.; Phillips, S.M. Differential stimulation of myofibrillar and sarcoplasmic protein synthesis with protein ingestion at rest and after resistance exercise. J. Physiol. 2009, 587, 897-904. [CrossRef] 
79. Francaux, M.; Demeulder, B.; Naslain, D.; Fortin, R.; Lutz, O.; Caty, G.; Deldicque, L. Aging reduces the activation of the mTORC1 pathway after resistance exercise and protein intake in human skeletal muscle: Potential role of REDD1 and impaired anabolic sensitivity. Nutrients 2016, 8, 47. [CrossRef]

80. Costamagna, D.; Costelli, P.; Sampaolesi, M.; Penna, F. Role of Inflammation in Muscle Homeostasis and Myogenesis. Mediat. Inflamm. 2015, 2015, 805172. [CrossRef]

81. Liao, C.D.; Chen, H.C.; Kuo, Y.C.; Tsauo, J.Y.; Huang, S.W.; Liou, T.H. Effects of muscle strength training on muscle mass gain and hypertrophy in older adults with osteoarthritis: A systematic review and meta-analysis. Arthr. Care Res. 2019. [CrossRef]

82. Thomas, D.K.; Quinn, M.A.; Saunders, D.H.; Greig, C.A. Protein Supplementation Does Not Significantly Augment the Effects of Resistance Exercise Training in Older Adults: A Systematic Review. J. Am. Med. Dir. Assoc. 2016, 17, e951-e959. [CrossRef]

83. Miller, P.E.; Alexander, D.D.; Perez, V. Effects of Whey Protein and Resistance Exercise on Body Composition: A Meta-Analysis of Randomized Controlled Trials. J. Am. Coll. Nutr. 2014, 33, 163-175. [CrossRef] [PubMed]

84. Gade, J.; Pedersen, R.J.; Beck, A.M. Effect of Protein or Essential Amino Acid Supplementation During Prolonged Resistance Exercise Training in Older Adults on Body Composition, Muscle Strength, and Physical Performance Parameters: A Systematic Review. Rehabil. Process Outcome 2018, 7. [CrossRef]

(C) 2020 by the authors. Licensee MDPI, Basel, Switzerland. This article is an open access article distributed under the terms and conditions of the Creative Commons Attribution (CC BY) license (http://creativecommons.org/licenses/by/4.0/). 